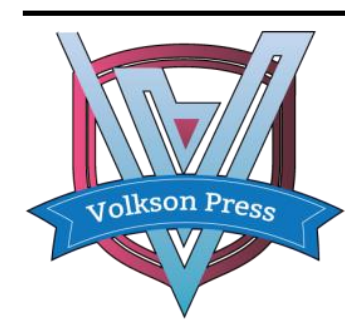

Contents List available at VOLKSON PRESS

Multidisciplinary Inclusive Education, Management

and Legal Services (MIEMLS)

Journal Homepage: https://topicsonsocialdevelop.com

DOI: $10.26480 /$ ismiemls.01.2018.07.09

ISBN : 978-1-948012-13-3

\title{
RESEARCH OVERVIEW ON GOVERNMENT PUBLIC RELATIONS
}

\author{
Yang Guangming* \\ School of Social Management, Kunming University, Kunming, China \\ *Corresponding author email: mgy6610@126.com
}

This is an open access article distributed under the Creative Commons Attribution License, which permits unrestricted use, distribution, and reproduction in any medium, provided the original work is properly cited.

\section{ARTICLE DETAILS}

\section{Article History:}

Received 26 June 2018

Accepted 2 July 2018

Available online 1 August 2018

\section{ABSTRACT}

Government public relations, as an effective means for the government to shape its own image and respond to public crisis, has been recently widely emphasized and adopted in our government departments. Government public relations, an important way to maintain the coordinated and benign government operation, are also a necessary prerequisite for maintaining social stability and harmonious development. This article about government public relations studies definition of government public relations, problems faced by our government public relations at the present stage and its countermeasures and proposes ways and methods to perfect our government image and establish good public relations.

\section{KEYWORDS}

Public relations, government public relations, social public, media.

\section{PUBLIC RELATIONS AND GOVERNMENT PUBLIC RELATIONS}

Public relations, as an objective existence, have almost begun to appear together with the formation of human society [1]. Dr. Harlow of the American Public Relations Research and Education Foundation holds that "Public relations serve as a unique management function that helps an organization to establish communication, understanding, recognition, and cooperation with its public; it is involved in handling of various issues and events; it helps administrative department to understand and respond to public opinion; it clearly stresses the responsibility of administrative department in serving the public interest; it helps the administrative department to grasp the changes in the situation, monitor these changes and predict the trend of change, so that organization simultaneously develop with social changes; it uses fine communication technology and research methods in line with professional ethics as the basic tools." This definition describing the basic connotation of public relations is recognized as the most comprehensive one, but it seems too verbose and lengthy, and does not meet the basic requirements of ordinary logic.

"Relations", without exception, always refers to the connection between things. The so-called "connection" refers to the interaction between things and between internal factors of things. The objective bearers of public relations as a relation are social organizations and the public [2]. Hence, public relation represents the interaction between social organizations and the public.

In the current social environment, all organizations or individuals are invariably wrapped in various very complicated public relations network environment. Government agencies constitute one type of organizations. The so-called government public relations refer to the public relations activities in which government serves as the behavioral agent of social organizations while social public serves as the object [3]. Such government public relation is a kind of communication activity which takes basis on specific political, economic, living conditions, and social conditions, "follows the principles of non-compulsory power, equality and voluntary selection, and establishes good relation with social public to maintain a good government image using soft strategies of two-way communication, persuasion and education. Its purpose is to establish and maintain a harmonious relationship between the government and the public, ensure smooth implementation of government's administrative policies, develop the interests of the country, society, and the public as a whole, set up a good image characterized by fairness, honesty, efficiency, pragmatism, full dedication to serving the people, and improve the government reputation."

As far as the nature of the government's public relation is concerned, the content, form, and skills of transmission and communication adopted by the public relation subjects will directly determine the state of government public relations [4]. The transmission and communication activities of public relations subjects will show benign characteristics if they conform to the trends and laws of social development and win public support, and will fall in vicious state vice versa.

The socialist harmonious society we intend to build is a society advocating democracy and rule of law, fairness and justice, integrity and friendliness, dynamism, stability and order, and harmony between man and nature, which means a complex and arduous social project that requires a long development process to constantly overcome various inharmonious factors, continuously adjust various interests, and continuously resolve various contradictions and controversies [5]. In this development process, government behavior is the key to building a harmonious society.

As the state administrative organ, the government is the executive organ of the state power that exercises basic duties of guidance, planning, management, coordination, service, supervision, defense in all aspects of national affairs. At the same time, the government is incessantly exposed to all kinds of relationships due to public nature of its work [6]. Hence, in the process of building a harmonious society, in addition to hard strategies in politics, economy and law, the government need resort to soft government public relations activities to improve the government's ability to coordinate and communicate, achieve democratization in management, and create good public opinion environment to improve government image, thereby maintaining social stability and unity, and safeguarding harmonious development of society [7]. 


\section{THE DEVELOPMENT STATUS OF OUR GOVERNMENT PUBLIC RELATIONS}

Our government has carried out several political structural reforms, with a view to establishing a highly democratic political system [8]. An important way to realize the purpose is to build a bridge of information exchange between the government and the people, to enhance political transparency and openness and people's awareness of political participation. The information exchange between the government and the people is actually one of its manifestations [9]. In the opinion of public relations, the government is also a social organization, and the government's public is the people, how the government achieves mutual understanding and cooperation with the people through communication activities is the content of the government's public relations activities.

An important aspect of political system reform is the establishment of a social consultation and dialogue system. In the past, Comrade Mao Zedong advocated the principles of grassroots work methods: "from the masses, to the masses, all for the masses, and all by the masses." However, for a long term, there has been no specific operation really solving this method. Seriously speaking, our government staff should not be accustomed to a one-way mode of communication to "preach, teach, and answer" [10]. Modern mass communication tools are not solely tools for governmental policy interpretation but should have serve as a tool for two-way information exchange between government and people. From the perspective of public relations, the social consultative dialogue system put forward by the party's "Thirteenth Party Congress" is to find the method for two-way information exchange between the people and the government, which is essentially a government public relation activity.

Seen from the current social environment, although social consultative dialogue system has been implemented to a certain exert with transparency of information disclosure on constant rise, government is also learning how to communicate and exchange with the public, administrating for the people and collecting ideas from the people, the overall situation is not entirely satisfactory. Various crisis events have occurred from time to time, like Yunnan Menglian Incident and Guizhou Weng'an Incident [11]. There is of course a variety of reasons, but it can be confirmed that the government's lack of necessary proficiency in handling crisis is one fundamental reason. At present, no specialized department for public relation has been established in all levels of government, there is generally no specialized public relations staff, which makes it difficult to ensure effective implementation of the social consultation and dialogue system. It can be speculated that with the deepening of political system reform and wide implementation of social consultation system, the study on government public relations will play an increasingly important role.

\section{COUNTERMEASURES TO IMPROVE OUR GOVERNMENT PUBLIC RELATIONS}

The government referred to in government public relations means the core sectors of the superstructure built on the socio-economic basis, including power institutions at various levels performing administrative, legislative, and judicial functions, as well as those performing macromanagement functions on behalf of the state. It also includes the ruling party institutions at all levels.

\section{a. Public interest should take the first place in government public relations}

The government is to play guidance, management, coordination, supervision, defense, and service role in all aspects of the country. Its power is authoritative, unchangeable and mandatory for the involved parties during the implementation. Therefore, how to embody the concept of "public interest first" in government public relations has become the primary goal. The specific tasks in this aspect include: First, listening to the public and earnestly taking their opinions to understand the public's impression of the government and using it as a reference for governance. Second, doing practical things, doing good things, and seeking profits for the public, which mainly means to improve the management benefits of the government and truly benefit the people and society. Third, giving to play the role of media, through expanding publicity on government guidelines and policies on the one hand, and strengthening the role of "media supervision". Fourth, setting up multiple channels of communication between the government and the public such as "mayor mailbox", "mayor hotline", "leadership reception day", "official Microblog, WeChat" to strengthen contact with the public as much as possible, and establish a good government image.

\section{b. Government public relations require efforts in information disclosure and timely release}

In modern society, with the increasing progress of society and the rapid development of science and technology, the entire social environment has become increasingly complicated, with "information explosion" becoming a prominent social phenomenon which makes government agencies increasingly assume the role of general information gatherer. Therefore, how to effectively collect, process, store, and disseminate information becomes another goal of government public relations. The government's specific tasks in this regard include: First, actively and systematically collecting information by extensively carrying out various types of social surveys on national conditions and public opinions to fully grasp diverse latest information; setting up a special investigation and statistics agency to make information collection and arrangement work departmental, professional, regular, and scientifically quantitative. Second, publicly disseminating information in a timely manner. The government shall promptly and effectively publish information among the general public through various information dissemination media (such as newspapers, radio, television, Internet, etc.) and channels (such as news conferences, press conferences, people's representative consultations, seminars, etc.), and constantly provide the media with materials of public concern.

The information disclosure and timely release of the "Wenchuan Earthquake" in 2008 in China became a much-told story in our history of government public relations, which made the international community have a completely new appraisal of Chinese government. In Wenchuan earthquake, the government's clear public relations information has historically surpassed the past as a large number of media reporters, including foreign media reporters, were allowed to enter the disaster area for interviews and reports. The National Press Office held regular press conferences and invited all relevant department personnel to introduce the situation of disasters and earthquake relief. In particular, it should be mentioned that 24-hour, virtually all-round live broadcast was provided over a period of time by China's major mass media such as the Central People's Broadcasting Station, China Central Television, etc., creating a new record in the domestic press. The state timely announced the amount and use of public donations and allowed audits and supervision by the auditing department. "New Weekly" claimed it as "great transparency, a national adult ceremony." Ma Zhen, president of the British newspaper "The Times" in Beijing, described what she saw and heard in Sichuan's disaster-stricken areas with "unprecedented news disclosure and surprisingly orderly order." Wenchuan Earthquake report serves as a satisfactory answer given by the government and the media after the official implementation of "Ordinance of Government Information Disclosure in People's Republic of China", which has a milestone significance in the Chinese news history. The highly transparent information has played a very important positive role in the earthquake relief work, not only increasing the efficiency of earthquake relief operations, preventing possible rumors, enhancing public confidence and sense of participation in earthquake relief activities, popularizing diverse disaster relief knowledge and growing government credibility.

\section{c. The relevant conditions of the government staff should be publicized in government public relations}

Government workers who perform power on behalf of the state directly concern success or failure of government public relations through quality, efficiency, and work style, and directly represent government image. Therefore, publicizing the relevant conditions of government workers is another task in government public relations. The specific contents include: First, regularly publishing political achievements of government officials, giving reasons for the promotion and dismissal to the public, letting representatives of the social public sign the cadres' work report. Second, 
the economic benefits, welfare standards, and family circumstances of government workers should be made aware to the social community except for privacy involving legal provisions, their personal circumstances should be more "transparent" than the general public. The recent series of events such as "Beijing Haze Incident" have shown that the public shows increasing concern for government workers as time goes by, while government workers face the supervision of the general public at any time and place. Third, the government should introduce the background of government officials who hold important positions to the public as much as possible. There are two significances here: giving the public a sense of intimacy which contributes to harmonious working relationships; expanding one's popularity which provides a better public foundation for conducting one's work.

\section{CONCLUSION}

As society enters a transitional period with concentrated outbreak of social conflicts, various intertwined interests, endless emergence of mass incidents, government credibility has been challenged and government image has been affected. Government public relations aim to realize the communication and interaction between the government and the public via some public relations means, so that the public understand government work, and win public support and trust. The effective practice of government public relations means important practical significance in coordinating social conflicts, maintaining and stabilizing social order, strengthening government staff's awareness of serving the people, promoting two-way exchanges of information between the government and the people, enhancing the government's ability to formulate and implement policies, developing democratic politics, strengthening the construction of an honest and clean government, and ultimately shaping a good government image.

\section{REFERENCES}

[1] Yanan, J. 2007. An Introduction to Public Relations [M]. Shanghai:
Shanghai People's Publishing House.

[2] Yanan, J., Jianhua, Z. 2017. Public Relations [M]. Shanghai: Fudan University Press.

[3] Chen, C. 2017. Improvement and increase of government public relations under a harmonious society [J]. Periodical Press of Shanxi Agricultural University, (6), 46-52.

[4] Weijian, L. 2010. Government Public Relations [M]. Beijing: Renmin University of China Press.

[5] Yunmao, Z. 2012. Public Relations and Modern Government [M]. Shanghai: Shanghai University Press.

[6] Minyan, P. 2014. On effective government public relations and its realization [J]. Journal of Guangdong Radio \& Television University, 18 (6), 60-63.

[7] Wei, Z. 2016. Research on the Improvement of Our Government Public Relations under the Background of Informatization [J]. Journal of Dalian University of Technology, 11 (6).

[8] Xiaoyu, W. 2018. Research on public relations in new media era under the background of government credibility construction [D]. Wuhan: Huazhong University of Science and Technology.

[9] Lisha, Z., Xianqing, L. 2004. The shaping of new government image calls for government public relations [J]. Science \& Technology Progress and Policy, (11), 78-81.

[10] Xiaofang, L. 2014. On the problems existing in our government public relations and ways to alleviate it [J]. Journal of Xizang Minzu University (Philosophy and Social Sciences), 21 (3), 45-47.

[11] Wenbo, Z. 2011. Analysis on Countermeasures to Improve Current Government Public Relations in China [J]. Journal of Handan College, (1), 56-58. 